\title{
Pengaruh Pemberian Teh Kombucha Konsentrasi 50\% dengan Waktu Fermentasi yang Berbeda pada Struktur Histologi Hepar Tikus Wistar (Rattus norvegicus) Jantan
}

\section{Effect of Giving Kombucha Tea Concentration of 50\% with Different Fermentation Times on Histological Structure of Liver of Wistar Rats (Rattus norvegicus) Male}

\author{
Sri Isdadiyanto dan Silvana Tana \\ Departemen Biologi, Fakultas Sains dan Matematika, Universitas Diponegoro \\ Jl. Prof. Soedarto, SH, Tembalang, Semarang \\ Corresponding Author : isdadiyanto@yahoo.com
}

\begin{abstract}
This study was conducted to determine the effect of 6 kombucha fermented tea (P1), 9 (P2) and 12 (P3) fermentation days at a concentration of 50\% on the liver histological structure and hepatocyte diameter. This study used 16 male white rats consisting of 4 treatments and 4 replications. The treatment of this study consisted of P0: control treatment; P1, P2 and P3 respectively were given 6, 9 and 12 days fermented kombucha tea at a concentration of 50\%. This research uses a completely randomized design. The variable measured in this study was the diameter of hepatocytes in test animals. The data obtained were analyzed using Analysis of Variance (ANOVA) at a 95\% confidence level and if there were real differences, followed by Duncan's test. The results of data analysis showed that kombucha tea fermented 6,9 and 12 days with a 50\% concentration did not have a significant difference in hepatocyte diameter variables. The histological structure of the liver looks normal and shows no sign of cell damage. It can be concluded that kombucha tea at a concentration of $50 \%$ is safe for consumption by mammals because it does not cause liver damage.
\end{abstract}

Key words: liver histology, kombucha tea, fermentation, wistar rat (Rattus norvegicus)

\begin{abstract}
Abstrak
Penelitian ini dilakukan untuk mengetahui pengaruh pemberian teh kombucha fermentasi 6 (P1), 9 (P2) dan 12 (P3) hari fermentasi pada konsentrasi 50\% terhadap struktur histologi hepar dan diameter hepatosit. Penelitian ini menggunakan 16 ekor tikus putih jantan terdiri atas 4 perlakuan dan 4 kali ulangan. Perlakuan penelitian ini terdiri dari P0 : perlakuan kontrol; P1, P2 dan P3 berturut-turut adalah pemberian teh kombucha fermentasi 6, 9 dan 12 hari pada konsentrasi 50\%. Penelitian ini menggunakan Rancangan Acak Lengkap. Variabel yang diukur pada penelitian ini adalah diameter hepatosit pada hewan uji. Data yang diperoleh dianalisis menggunakan Analysis of Variance (ANOVA) pada taraf kepercayaan $95 \%$ dan apabila terdapat perbedaan nyata, dilanjutkan uji Duncan. Hasil analisis data menunjukkan bahwa teh kombucha fermentasi 6,9 dan 12 hari konsentrasi 50\% tidak memiliki perbedaan nyata terhadap variable diameter hepatosit. Struktur histologi hepar terlihat normal dan tidak menunjukkan ciri-ciri kerusakan sel. Hal ini dapat disimpulkan bahwa teh kombucha pada konsentrasi 50\% aman dikonsumsi oleh mammalia karena tidak menimbulkan efek kerusakan hepar.
\end{abstract}

\section{Kata kunci : histologi hepar, teh kombucha, fermentasi, tikus wistar (Rattus norvegicus)}

\section{PENDAHULUAN}

Hepar merupakan Salah satu organ di dalam tubuh yang mempunyai peran penting sebagai detoksifikasi senyawa asing atau toksik. Hepar mempunyai fungsi dalam biotransformasi zat-zat yang bersifat toksik menjadi zat-zat yang tidak toksik. Biotranformasi ini yang menyebabkan sel hepar dapat terjadi kerusakan, dapat terjadi kerusakan struktur sel maupun berupa mal fungsi hepar (Aisyah, 2015). Hepar mempunyai beberapa sel antara lain hepatosit dan sel makrofag yang disebut sebagai sel Kupffer. Sel hepatosit membentuk stuktur berderet secara radier dalam lobulus hepar dan membentuk lapisan 1-2 sel. Lempeng-lempeng sel ini mengarah dari tepian lobulus ke pusatnya dan beranastomosis secara bebas membentuk struktur seperti labirin dan busa. Celah diantara lempeng- lempeng ini mengandung kapiler yang disebut sinusoid hepar. Aliran darah menuju ke vena sentralis dari portal triad, sedangkan aliran bile menuju ke portal triad dari dalam lobules (Junquiera et al, 2007). 
Penelitian Afdina (2016) menjelaskan bahwa senyawa-senyawa herbal yang dikonsumsi akan mengalami proses absorbsi, distribusi, metabolisme dan ekskresi. Hepar merupakan organ utama yang sering mengalami kerusakan karena senyawa yang dikonsumsi atau deposit metabolit. Metabolisme akan dilakukan terhadap senyawa yang dikonsumsi di hepar dan perubahan struktur kimia akan terjadi yang dikatalisis oleh enzim yang disebut biotransformasi. Metabolit yang biasanya kurang aktif dari obat asalnya akan terjadi dari proses pengubahan senyawa obat atau herbal yang dikonsumsi. Proses metabolisme obat tidak selalu merupakan proses detoksikasi obat atau eliminasi persenyawaan tersebut, kadangkadang terjadi transformasi obat menjadi senyawa intermediet yang reaktif dan toksik terhadap hepar. Perubahan struktur dan perubahan fungsi akan terjadi pada kasus cedera hepar akut karena terjadi perubahan metabolisme.

Teh kombucha merupakan hasil dari fermentasi beberapa bakteri dan ragi membentuk - jamur teh yang merupakan minuman perpaduan rasa manis dan asam yang menyegarkan (Chen dan Liu, 2000). Teh kombucha disiapkan dengan membuat kultur kombucha (teh jamur) menjadi media teh manis untuk proses fermentasi (Loncar et al, 2000). Teh kombucha merupakan nama umum yang diberikan untuk pertumbuhan simbiosis bakteri asam asetat dan spesies ragi osmofilik di membran jamur yang dibudidayakan dalam teh manis (Jarrell, 2000). Teh kombucha bukanlah sebuah -jamur melainkan asosiasi ragi dan bakteri (Jayabalan et al, 2014). Nugraha et al.(2018) menyatakan bahwa teh kombucha fermentasi 6, 9 dan 12 hari konsentrasi $100 \%$ struktur histologi hepar terlihat normal dan tidak menunjukkan ciri-ciri kerusakan sel. Isdadiyanto dan Tana (2019) menyatakan bahwa teh kombucha fermentasi 6, 9 dan 12 hari konsentrasi $50 \%$ tidak menunjukkan ciri-ciri kerusakan sel pada struktur histologi hepar.

Jayabalan et al. (2014) menyebutkan bahwa beberapa penelitian mengaitkan manfaat dari teh kombucha, salah satunya ialah sebagai hepatoprotector. Teh kombucha telah dipelajari hepatoprotektifnya terhadap berbagai polutan lingkungan pada model hewan dan sel line. Penelitian ini telah diuji untuk mengkaji hepatoprotektif teh kombucha (disiapkan dari teh hitam) terhadap parasetamol (Pauline et al., 2001), karbon tetra klorida (Murugesan et al, 2009), aflatoksin B1 (Jayabalan et al, 2010). Berbanding terbalik dengan Kusumah (2008) menjelaskan bahwa pemberian teh kombucha per oral terjadi perubahan struktur histologi sel hepar pada semua tingkat dosis yaitu dosis $0,26 \mathrm{ml} 2 \mathrm{x} / \mathrm{hari} 0,52 \mathrm{ml}$ $2 \mathrm{x} /$ hari $0,39 \mathrm{ml} 2 \mathrm{x} /$ hari menghasilkan degenerasi parenkimatosa, degenerasi hidropik sampai dengan nekrosis. Berdasarkan latar belakang di atas, perlu dilakukan penelitian pemberian teh kombucha terhadap hewan uji tikus putih sebagai uji praklinis untuk mengetahui dampak yang sebenarnya terjadi pada hepar setelah perlakuan.

\section{BAHAN DAN METODE}

Penelitian dilakukan di Laboratorium Biologi Struktur dan Fungsi Hewan, Departemen Biologi Fakultas Sains dan Matematika, Universitas Diponegoro Semarang, pada bulan Mei sampai Juli 2016. Tikus Wistar (Rattus norvegicus) jantan sebanyak 16 ekor umur 2 bulan, digunakan bahan perlakuan yaitu Teh kombucha kadar 50\% yang difermentasi selama 6, 9 dan 12 hari pada suhu $25^{\circ} \mathrm{C}$ dengan spuit injeksi ujung berkanul per oral. Alat-alat yang digunakan yaitu 20 kandang individu yang dilengkapi dengan tempat minum dan pakan, gelas ukur, timbangan digital dan alat diseksi.

Penelitian ini menggunakan Rancangan Acak Lengkap (RAL) dengan 4 perlakuan dan 4 ulangan yaitu : $\mathrm{P} 0=$ kontrol, tanpa tambahan teh kombucha, $\mathrm{P} 1=$ air minum $+1,8 \mathrm{ml}$ teh kombucha kadar $75 \%$ pagi dan sore fermentasi 6 hari, $\mathrm{P} 2=$ air minum $+1,8 \mathrm{ml}$ teh kombucha kadar 50\% pagi dan sore fermentasi 9 hari, $\mathrm{P} 3=$ air minum $+1,8 \mathrm{ml}$ teh kombucha kadar 50\% pagi dan sore fermentasi 12 hari. Pakan dan minum diberikan secara ad libitum. Variabel penelitian terdiri dari variabel bebas dan variabel terikat sebagai berikut: Variabel bebas adalah perlakuan oral teh kombucha fermentasi 6, 9 dan 12 hari konsentrasi $50 \%$. Variabel terikat meliputi struktur histologi hepar dan diameter hepatosit. Gambaran struktur histologi hepar dianalisa secara deskriptif. Perhitungan diameter hepatosit dilakukan dengan cara memilih secara acak 5 hepatosit terdekat pada vena sentralis, kemudian dirata-rata. Setiap hepatosit dijumlahkan sisi terlebar + sisi tersempit, lalu dibagi 2. Analisis data diameter hepatosit dilakukan uji normalitas Shapiro-wilk (Oktaviana, 2013), pada taraf kepercayaan 95\% dilanjutkan uji ANOVA (Mattjik dan Sumertajaya, 2006) dan apabila terdapat beda nyata, dilanjutkan dengan uji Duncan. Seluruh data kuantitatif akan dianalisa menggunakan bantuan aplikasi SPSS 16 (Saputro, 2013). 


\section{HASIL DAN PEMBAHASAN}

Hasil analisis terhadap diameter hepatosit tikus Wistar jantan pada perlakuan teh kombucha konsentrasi $50 \%$ dengan waktu fermentasi yang berbeda disajikan pada Tabel 1. Teh kombucha konsentrasi 50\% dengan waktu fermentasi 6, 9 dan 12 hari menunjukkan hasil yang tidak berbeda nyata terhadap diameter hepatosit. Fermentasi teh kombucha dilakukan secara aerob, sehingga akan dihasilkan metabolit sekunder yaitu alkohol (Loncar et al, 2000). Gambar 1. menunjukkan kondisi hepar kontrol pada perbesaran 100 kali (A) dan 200 kali (B). Lumen vena sentralis (VS) dan portal triad (PT) terlihat jelas pada gambar mikroskopis perbesaran 100 kali. Hepatosit (H) dan sinusoid (S) yang merupakan saluran antara portal triad dan vena sentralis terlihat dengan jelas pada perbesaran 200 kali. Pewarnaan hematoksilin-eosin mewarnai merah muda untuk sitoplasma dan biru tua untuk inti. Hepatosit dapat terlihat pada perbesaran 400 kali seperti pada Gambar C. Hepatosit pada tanda panah terlihat jelas inti bewarna biru tua dan berbentuk bulat. Struktur inti dapat dilihat untuk mengidentifikasi kerusakan sel.
Tabel 1. Hasil analisis rata-rata diameter hepatosit tikus Wistar setelah pemberian teh kombucha konsentrasi $50 \%$ dengan waktu fermentasi yang berbeda

\begin{tabular}{lcccr}
\hline \multicolumn{1}{c}{$\begin{array}{l}\text { Variab } \\
\text { el }\end{array}$} & P0 & P1 & P2 & P3 \\
\hline $\begin{array}{l}\text { Diameter } \\
\begin{array}{l}\text { Hepatosit } \\
(\mu \mathrm{m})\end{array}\end{array}$ & $14,75^{\mathrm{a}}$ & $13,56^{\mathrm{a}} \pm$ & $14,54^{\mathrm{a}} \pm$ & $15,04^{\mathrm{a}} \pm$ \\
& & 3,23 & 2,29 & 2,17 \\
& & & &
\end{tabular}

Keterangan : Angka dengan superskrip yang sama pada satu baris menunjukkan tidak berbeda nyata pada taraf kepercayaan $95 \%$.

Price dan Lorraine (2006) menjelaskan bahwa bahan toksik seperti alkohol dapat menganggu proses metabolisme di hepar, Sehingga dapat menyebabkan kerusakan sel bahkan sampai pada tahap kematian sel /nekrosis. Chen and Liu (2000) menjelaskan bahwa teh kombucha dibuat dengan cara fermentasi aerob. Dalam proses metabolismenya melibatkan unsur $\mathrm{O}_{2}$ untuk fermentasinya. Salah satu metabolit sekunder yang dihasilkan oleh proses fermentasi adalah ethanol. Konsentrasi ethanol meningkat dengan berjalannya waktu dan akan menghasilkan kandungan ethanol tertinggi $5,5 \mathrm{~g} / \mathrm{L}$ atau $0,5 \%$ kemudian diikuti penurunan lambat konsentrasi ethanol di waktu selanjutnya
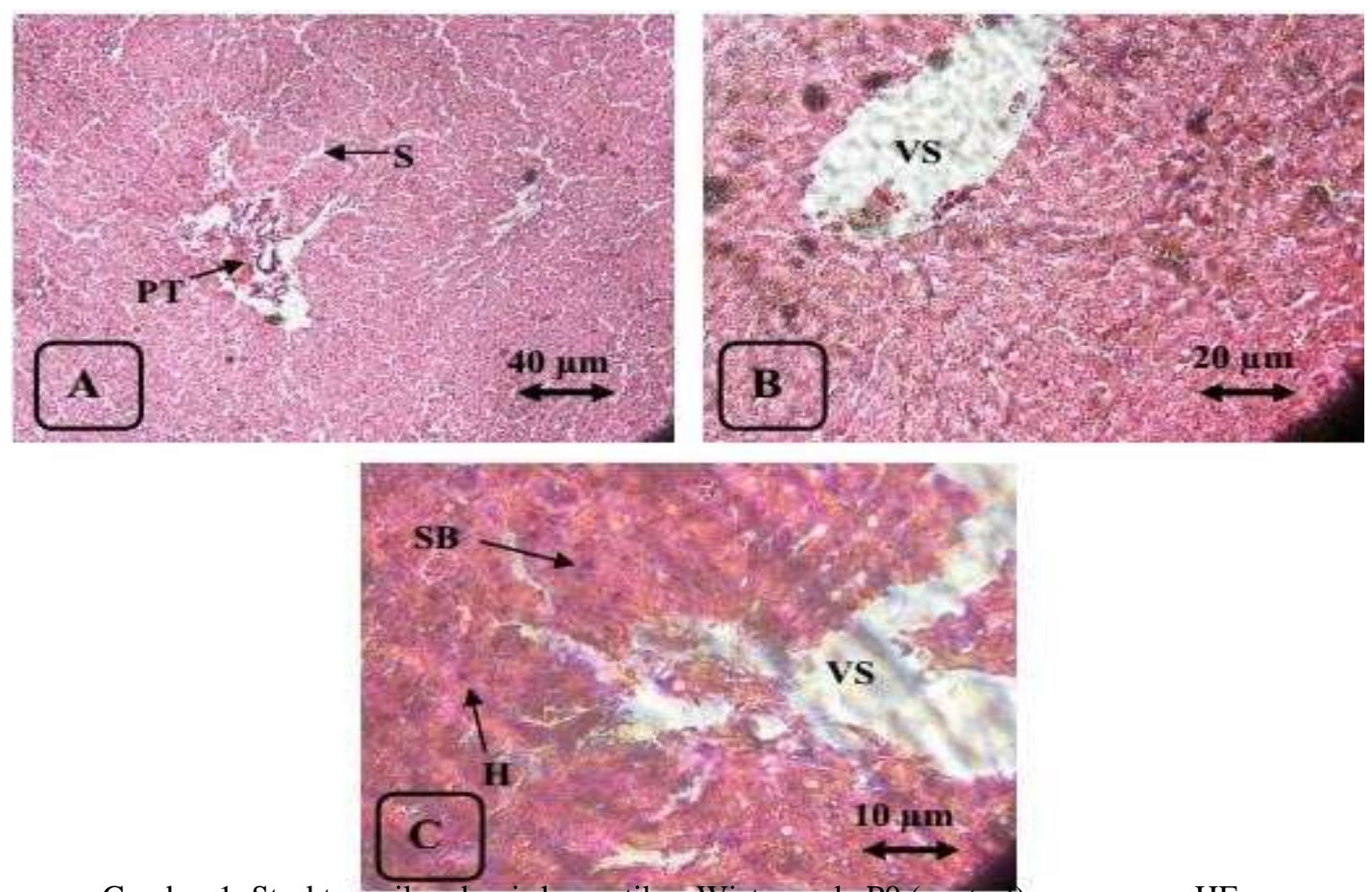

Gambar 1. Struktur mikroskopis hepar tikus Wistar pada P0 (controI), pewarnaan HE

Keterangan : A. Perbesaran 100x, B. Perbesaran 200x, C. Perbesaran 400x, VS : vena sentralis, H : hepatosit, PT : portal triad, $\mathrm{S}$ : sinusoid, $\mathrm{SB}$ : sel binukleat 
Jayabalan et al. (2014) menjelaskan bahwa kandungan ethanol maksimal diperoleh pada proses fermentasi hari ke 6. Kemenperin RI (2017) menjelaskan bahwa penjualan minuman beralkohol di Indonesia yang diijinkan dan tergolong aman adalah sama dengan atau kurang dari 5\% ini termasuk golongan A. Zakhari (2006) menjelaskan bahwa serangkaian proses biokimia akan terjadi bila alkohol masuk ke dalam tubuh makluk hidup. Tubuh akan melakukan metabolisme $90 \%$ alkohol yang dikomsumsi, diantaranya akan dimetabolisme terutama hati oleh enzim ADH (alkohol dehirogenase) dan koenzim NAD (nikotinamid-adenin- dinokleotida) terbentuk asetaldehid, kemudian oleh enzim ALDH (aldehida dehydrogenase) dikonversi menjadi asam asetat. Asam asetat selanjutnya mengalami oksidasi terbentuk $\mathrm{CO}_{2}$ dan $\mathrm{H}_{2} \mathrm{O}$. Metabolisme alkohol akan dipercepat oleh piruvat, levulosa (fruktosa), gliseraldehida dan alanin . Alkohol akan diubah menjadi asetaldehid, kemudian akan diubah menjadi asetat oleh ALDH di dalam mitokondria. Perubahan pada mitokondria akan terjadi pada pemakaian alkohol jangka waktu lama, sehingga akan menyebabkan terjadinya nekrosis karena berkurangnya kapasitas untuk oksidasi lemak.

Struktur histologi hepar pada kelompok P1, P2 dan P3 tidak memiliki perbedaan nyata dengan P0 (kontrol). Ketiga preparat perlakuan tersebut dapat dilihat pada Gambar 2, Gambar 3 dan Gambar 4
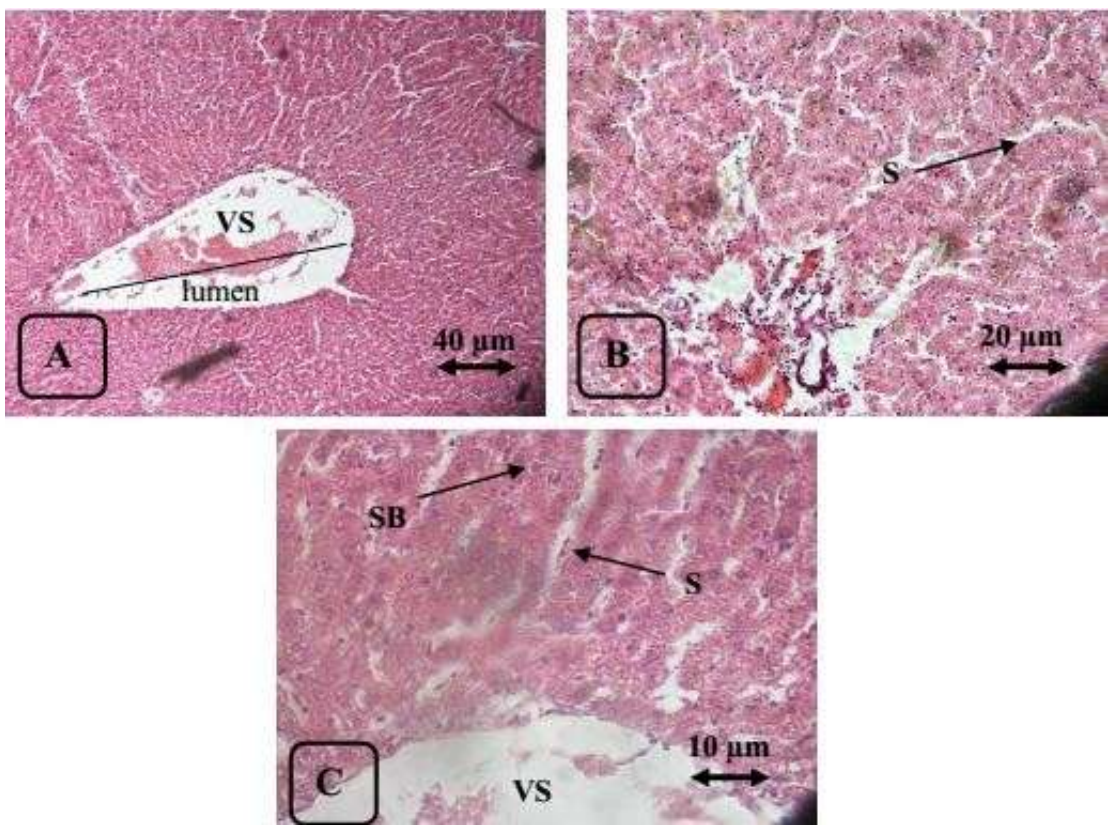

Gambar 2. Struktur mikroskopis hepar tikus Wistar pada perlakuan teh kombucha fermentasi 6 hari konsentrasi $50 \%$ (P1) pewarnaan HE.

Keterangan : A. Perbesaran 100x, B. Perbesaran 200x, C. Perbesaran 400x, VS : vena sentralis, S : sinusoid, SB : sel binukleat

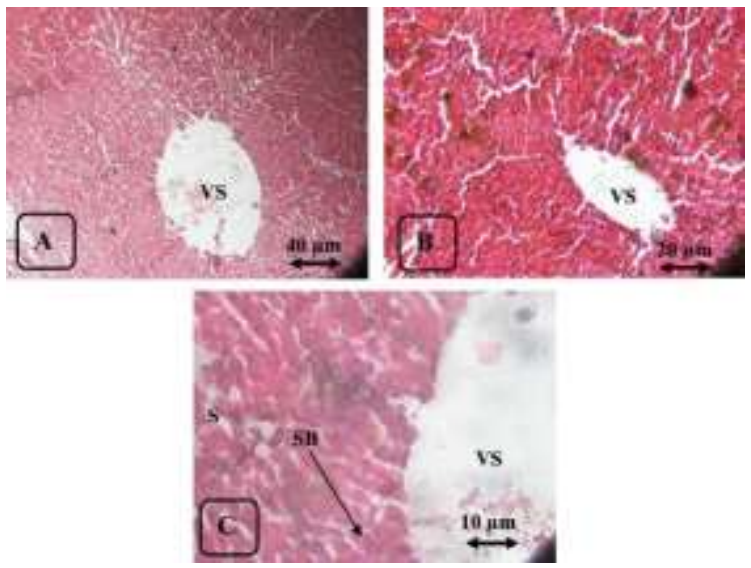

Gambar 3. Struktur mikroskopis hepar tikus Wistar pada perlakuan teh kombucha fermentasi 9 hari konsentrasi $50 \%$ (P2) pewarnaan HE. Keterangan : A. Perbesaran 100x, B. Perbesaran 200x, C. Perbesaran 400x, VS : vena sentralis, $\mathrm{S}$ : sinusoid, SB : sel binukleat 


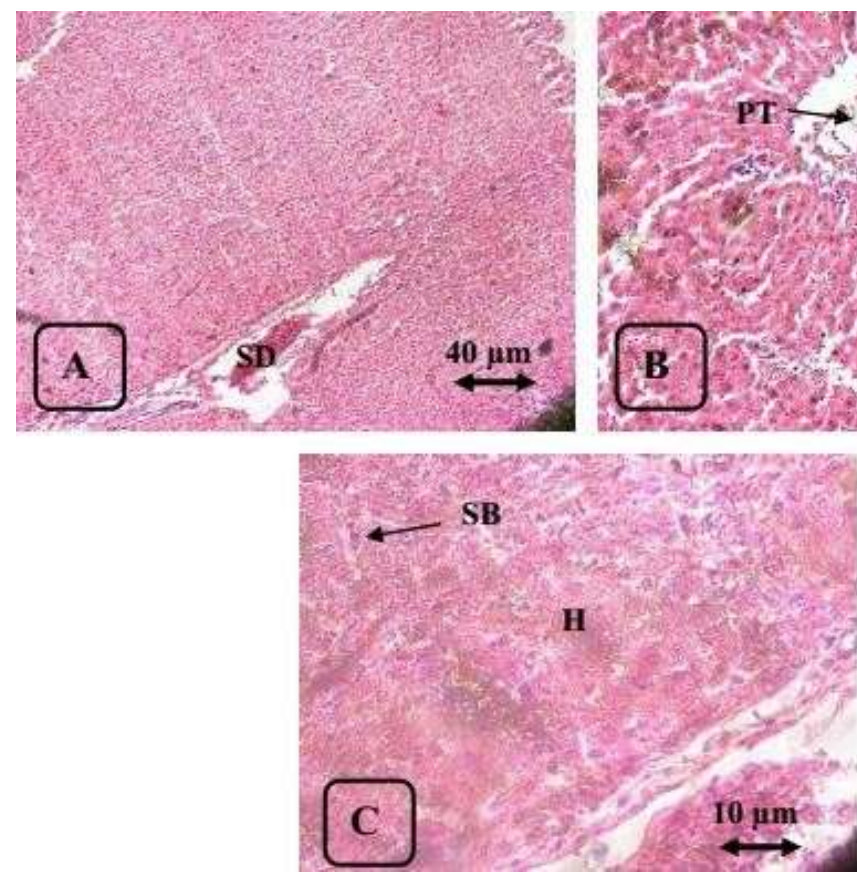

Gambar 4. Struktur mikroskopis hepar tikus wistar pada perlakuan teh kombuha fermentasi 12 hari konsentrasi $50 \%$ (P3) pewarnaan HE.

Keterangan : A. Perbesaran 100x, B. Perbesaran 200x, C. Perbesaran 400x, VS : vena sentralis, H : hepatosit, PT : portal triad, S : sinusoid, SB : sel binukleat

Preparat P1, P2 dan P3 tidak berbeda dengan kontrol (P0), yaitu seluruh preparat tidak menunjukkan adanya perbedaan yang nyata terhadap perlakuan. Hal ini menunjukkan bahwa the kombucha tidak mempengaruhi diameter hepatosit.

Beberapa preparat menunjukkan adanya proses regenerasi sel terjadi ditunjukkan dengan adanya sel binukleat atau sel yang mempunyai dua inti yang saling berkaitan. Anindyaputri (2017) menjelaskan bahwa sel hepatosit dapat melakukan proses regenerasi, proses membelah diri secara mitosis akan terjadi pada sel parenkim hepar. Hepatosit dapat menggandakan diri atau membelah prosesnya hamper sama dengan sel induk /sel punca. Setelah hepatosit memperbanyak diri, sel yang lain akan mengikuti dan membelah menjadi beragam sel yang berbeda. Sebuah struktur baru akan terbentuk dari sel-sel baru tersebut,yaitu mirip lobulus hepar baru. Kemampuan regenerasi ini dapat dilakukan jika kerusakan hepatosit yang terjadi pada tahapan reversibel atau ringan.
Hasil penelitian dan pembahasan di atas menunjukkan bahwa diameter sel hepatosit pada jaringan hepar tidak berbeda nyata, sehingga variabel tersebut tidak dipengaruhi oleh ketiga perlakuan

\section{KESIMPULAN}

Berdasarkan hasil penelitian, maka dapat disimpulkan bahwa pemberian $1,8 \mathrm{ml}$ teh kombucha fermentasi 6, 9, dan 12 hari konsentrasi $50 \%$ selama 35 hari tidak mempengaruhi diameter hepatosit hepar. Hal ini menunjukkan bahwa kombucha aman dikonsumsi oleh mammalia karena tidak menimbulkan efek kerusakan hepar.

\section{DAFTAR PUSTAKA}

Afdina, M. 2016. Peran dan Fungsi Sel yang terdapat pada Orga Hepar. Skripsi. Bandung. Sekolah Tinggi Farmasi Indonesia.

Aisyah, S., H. Budiman., D. Florenstina., dan D. Aliza. 2015. Efek pemberian Minyak Jelantah terhadap Gambaran Histopatologis Hati TikusPutih.Jurnal Media Veterinaria. 9(1) : 23.

Anindyaputri, I. $2017 . \quad$ Hepar Manusia:Regenerasi Sel.Jakarta.Hello 
Sehat Media Informasi Kesehatan.

Anugrah, S. T. 2005. Pengembangan Produk Kombucha Prebiotik Berbahan Baku Teh Hitam (Camelia Sinensis). Skripsi. Fakultas Teknologi Pertanian. Institut Pertanian Bogor.

Chen and Liu, 2000. Changes in major components of tea fungus metabolites during prolonged fermentation. Journal Applied Microbiology 89:834-9.

Isdadiyanto S. and Tana S. 2019. Struktur Histologi Hepar Tikus Wistar (Rattus norvegicus) Jantan setelah Pemberian Teh Kombucha Konsentrasi $75 \%$ dengan Waktu Fermentasi yang Berbeda. Jurnal Bioma Berkala Ilmiah Biologi. 21 (2): 6067.

Janquiera, L. C., and J. Carnaeiro. 2002. Histologi Dasar. Alih Bahasa Adji Dharma. Penerbit Buku Kedokteran, Jakarta.

Jarrel, T., and J. W. Bennett. 2000. The Kombucha Consortia of Yeast and Bacteria. Journal Mycologist. 14:166-70.

Jayabalan, R., S. Baskaran., S. Marimuthu., K. Swaminathan., and S. E. Yun. 2010. Effect of Kombucha on Aflatoxin B1 Induced Acute Hepatotoxicity in Albinorats-Prophylactic and Curative Studies. Journal Applied Biology Chemical 53:407-16.

Jayabalan, R., V. Radomir., E. Malbasa., E. S. Loncar., S.Jasmina., S. Muthuswamy.2014.Comprehensiv

Reviews in Food Science and Food Safety. Volume 13. A review of Kombucha Tea-Microbiology, Composition, Fermentation, Benefical Effect, Toxicity, and Tea Fungus. Journal Institute of Food Technologists. Doi : 10.1111/1541 4337.12073

Kemenperin.go.id/artikel/8338/Standar kandungan minuman alkohol berlabel SNI. Diakeses 25 Desember 2017

Loncar, E. S., S. E. Petrovic., R. V. Malbasa., and

R. M. Verac. 2000. Biosynthesis of Glucuronic Acid by Means of Tea Fungus. Comprehensive Reviews in Food Science and Food Safety. Nahrung 44:138-9.

Mattjik, A. A., dan I. M. Sumertajaya. 2006. Perancangan Percobaan dengan Aplikasi
SAS dan Minitab. Ed. Ke-3. IPB-Press. Bogor.

Muliani, H. 2015. Kadar Kolesterol Hepar Ayam Broiler setelah Pemberian Teh Kombucha. Buletin Anatomi dan Fisiologi Volume XXIII, Nomor 2.

Murugesan, G. S., M. Sathishkumar., R. Jayabalan., A. R.Binupriya., K. Swaminathan., and S. E. Yun. 2009. Hepatoprotectiveand curative properties of Kombucha tea against carbon tetrachloride-induced toxicity. Journal Microbiol Biotechnology 19:397 -402.

Nugraha A.P., Isdadiyanto S. and Tana S. 2018. Histopatologi hepar tikus wistar (rattus norvegicus) jantan setelah pemberian teh kombucha konsentrasi $100 \%$ dengan waktu fermentasi yang berbeda. Journal Anfis. 3(1):71-78.

Oktaviana, 2013. Uji Normalitas Berdasarkan MetodeAndersonDarling. FMIPA UNY. Yogyakarta.

Pauline, T., P. Dipti., B. Anju., S. Kavimani., S. K.Sharma., A. K. Kain., S. K. Sarada., M. Sairam., G. Ilavazhagan., K. Devendra., and W. Selvamurthy. 2001. Studies on toxicity, anti-stress and hepatoprotectivepropertiesof Kombuc tea. Biomed Environtment Science 14:207-1.

Permana, Z. 2010. Konsumsi, Kecernaan dan Konsumsi Tikus Putih (Rattus norvegicus) yang Disuplementasi Biomineral Cairan Rumen dalam Ransum. Skripsi. Fakultas Peternakan. InstitutPertanianBogor.

Price, S. A., dan M. W. Lorraine., 2006. Patofisiologi : Konsep Klinis ProsesProses Penyakit. Edisi 6. Volume 1. Jakarta : EGC.

Saputro, R. 2013. Statistik Terapan : Ilmu Kesehatan Masyarakat. Padang Stikes PerintisSumatera Barat.

Wolfenshon., and Lloyd. 2013. Handbook of Laboratory Animal Management and Welfare, 4th ed., Wiley-Blackwell : West Sussex, 234.

Zakhari, S. 2006. Overview: how is alcohol metabolized by the body ?. National Institute on Alcohol Abuse and Alcoholism (NIAAA) 5635, Fisher Lane. MSC 9304 Behe 